\title{
Optimization Design of Multifunction Machines for Making 2 Kinds of Animal Feed
}

\author{
Fadwah Maghfurah ${ }^{a}$, Riki Effendib, Rudiartoc \\ a,b,c Universitas Muhammadiyah Jakarta \\ JI. Cempaka Putih Tengah 27, DKI Jakarta, Indonesia \\ Telephone +6221-4256024 Ext.143 / Fax +6221-4256023 \\ e-mail: fadwah.maghfurah@ftumi.ac.id
}

\begin{abstract}
Optimization design of multifunctional machines for making of animal feed is one of the development efforts of conventional machinery to be a multifunctional machine with electric motor drive which is to help small MSME industries so that their results and capacity are faster and more effective during the process of milling and grinding. This is a new concept designed to increase the time effectiveness of its use. This tool is specifically designed to chop odot grass and grind corn kernels, where the tool works using resources from an electric motor that moves a U-type blade or type I blade for knitting or grinding. The method used to make multifunction machines includes the development of existing models, seeking research on previous tools, refining the design model concept, making $3 D$ models using the Solidworks Computer Aided Design (CAD) with a cycle time of 50 seconds on different test pieces and mills where assembly time is needed to complete the multifunction machine for \pm 20 days or 28800 minutes.
\end{abstract}

Keywords: optimazation design; electric motor; hopping odot grass; seeds of corn

\section{INTRODUCTION}

Animal feed plays a very important role in the livestock production chain, such as farmers in the Ligung-Majalengka village who raise goats and poultry. Forage feed referred to here is odot grass, odot grass is a green source of high nutritious food and is very well consumed routinely by goats and sheep and during this time among Ruminansia farmers are accustomed to seeing and utilizing Elephant Grass or King Grass or some who call it the term kolonjono, but no one has cultivated odot grass.

In addition to grass odot there are still many types that are used as animal feed such as corn and beans. The presentation of animal feed is usually presented directly without prior treatment and handling. This can reduce the efficiency of feed use because it is not consumed or is scattered to the ground. One way to increase the effectiveness of feeding is to feed or chop feed first. The presentation of feed such as this makes it easy for the animals to eat, so that all the food served can be eaten up and can be more easily digested. Scaffolding is intended to reduce the size of forage feed. In addition to the small size of serving feed, it becomes more effective, also allows mixing with additional feed ingredients. The forage feeds carried out by farmers are mostly still traditional in nature, namely manually cutting using a scythe or machete blade. For small farmers this method is still considered adequate. But for medium and large farmers, this method is less effective because it takes more time and energy. In addition, the use of sickles is less safe for people who chop the feed as well as grain.

\section{Methods}

The method used in the design of multifunctional animal feed machines is to design the design of parts and make material selection and calculate the strength or power of the multifunctional animal feed machine manually. 


\subsection{Flow Diagram}

In this study carried out by the following steps:

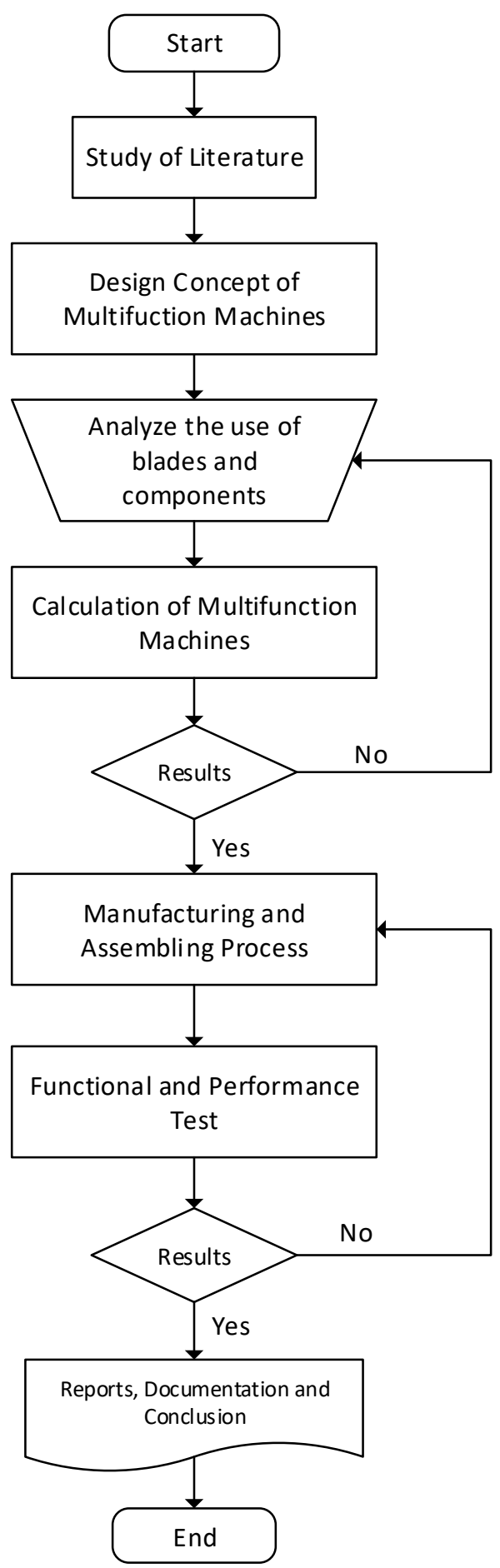

Figure 1. Flow chart for making machines for making animal feed

In assembling multifunctional machines for making this animal feed first by designing machines, namely by using the Solidworks application. The following is the design of a multifunctional animal feed machine. 


\subsection{Design Concept}

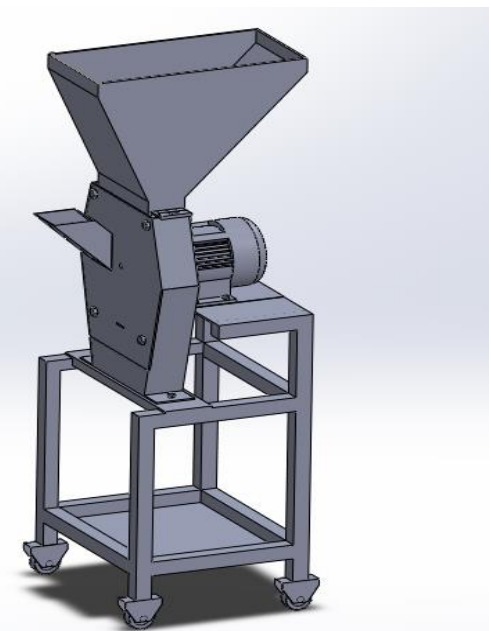

Figure 2. Concept Design with Solidworks

\section{RESULTS AND DISCUSSION}

\subsection{Determining The Line Round.}

From the results of measurements of grass mass in the field obtained:

1 grass stem odot $=2.08$ gram

25 grass sticks odot $=52$ gram

Where:

$\mathrm{Q}=$ planned output $50 \mathrm{~kg} / \mathrm{hour}$

$\mathrm{Z}$ = planned for two blades

$\mathrm{m}=2.08 \mathrm{gram}=0.00208 \mathrm{~kg} /$ rotation

$\mathrm{np}=$ rotation round

so that:

$\mathrm{m}=\frac{52 \mathrm{gram}}{25 \text { stem }}=2.08 \mathrm{gram}=\frac{2.08 \mathrm{gram}}{1000}=0.00208 \mathrm{~kg}$

and,

$\mathrm{np}=\frac{\mathrm{Q}}{\mathrm{m} \cdot \mathrm{z}} \quad x \frac{1 \text { hour }}{60 \text { secon }}$

$$
=\frac{50 \mathrm{~kg} / \text { hour }}{0.00208 \mathrm{~kg} / \operatorname{rot} x 2} \quad x \quad \frac{1 \text { hour }}{60 \text { minutes }}=200.32 \mathrm{rpm}
$$

\subsection{Determining Power and Torsion Required for Submission}

Based on the calculation of the odot cut grass force that has been known, then the next plan can be estimated the power needed, to calculate the plan power $(\mathrm{P})$ first calculate the torque produced from the odot cutting force.
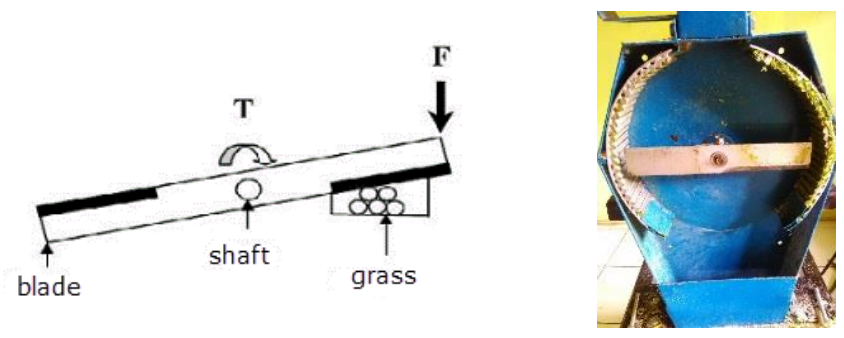

Figure 3. Cutting force on the blade 
a) The torque acting on the blade

- Total blade length $=260 \mathrm{~mm}$

- Blade length $=220 \mathrm{~mm}$

$-1 / 2$ Blade length $=110 \mathrm{~mm}$

- Cut style $(F)=3.2 \mathrm{~kg}$

$$
\begin{aligned}
\mathrm{T} & =\mathrm{F} \times \mathrm{r} \\
& =3.2 \mathrm{~kg} \times 110 \mathrm{~mm} \\
& =352 \mathrm{~kg} . \mathrm{mm}
\end{aligned}
$$

b) Machine power needed

$$
\begin{aligned}
& \mathrm{P}= \frac{T \cdot n}{9.74 \times 10^{5}} \\
&= \frac{352 \mathrm{~kg} \cdot 200.32 \mathrm{rpm}}{9.74 \times 10^{5}} \\
&= 0.072 \mathrm{KW} \\
&= 0.10 \mathrm{HP} \text { dgn } 1400 \mathrm{rpm} \\
& \text { were }: 1 \mathrm{HP}=745.7 \mathrm{Watt} \\
&=0.7457 \mathrm{KW} \\
& 0.5 \mathrm{HP}=\frac{745.7}{2}=372 \mathrm{Watt} \\
&=0.372 \mathrm{~kW}
\end{aligned}
$$

\subsection{Determining The Mixed Force of Corn Seeds}

In determining the milling force by calculating the mass of corn kernels first, then from the results of measuring corn kernels in the field by taking samples of 5 dry corn kernels as measured by digital balance in getting a mass of $=1.25 \mathrm{gram}$, to determine the average mass of 1 corn seed then,

1 corn seed mass $=\frac{1.25 \mathrm{gram}}{5}=0.25 \mathrm{gram}$

So, the average mass of 1 corn seed is between 0.25 gram.

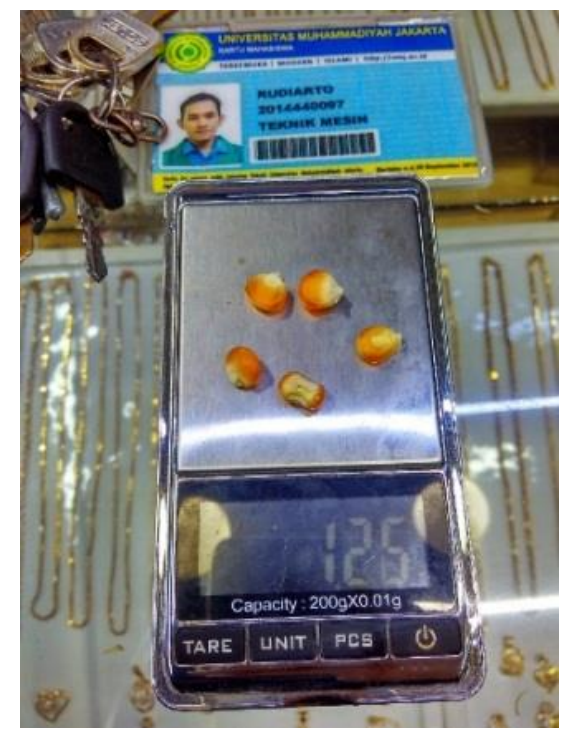

Figure 4. Measurement of Corn Seed Mass 
Table 1. Results Characteristics of dried corn kernels

\begin{tabular}{lc}
\hline \multicolumn{1}{c}{ Component } & Value \\
\hline water content & $11.49 \%$ \\
ash content & $1.55 \%$ \\
protein content & $8.92 \%$ \\
fat level & $5.44 \%$ \\
crude fiber content & $5.10 \%$ \\
starch content & $47.13 \%$ \\
amylose content & $20.24 \%$ \\
corn seed hardness & 87.85 \\
density & $0.735 \%$ \\
\hline \multicolumn{2}{c}{ Source: (BPPT, 2009) }
\end{tabular}

Likewise the crude fiber content must be able to reduce from $5.1 \%$ to a maximum of $1.2 \%$ (USDA, 2008) and a maximum of $1.5 \%$. (BSN, 1995). The milling force needed to determine the electric motor power needed on the machine is carried out by testing the hardness of corn kernels. For data on the results of testing of dried corn kernels can be seen in table 12. The results of hardness of dry corn kernels show a hardness value of 87.85 N = 8.96 kgf (BPPT, 2009).

\subsection{Determining The Milling Round (Np)}

From the results of measurements of grass mass in the field obtained:

1 dry corn seed $=0.25$ gram

5 dried corn seeds $=1.25$ gram

where:

$\mathrm{Q}=$ planned output $15 \mathrm{~kg} / \mathrm{hour}$

$\mathrm{Z}=$ planned for four blades

$\mathrm{m}=0.25 \mathrm{gram}=0.00025 \mathrm{~kg} /$ rotation

$\mathrm{np}=$ grinding round

$$
\begin{aligned}
& \mathrm{m}=\frac{1.25 \text { gram }}{5}=0.25 \text { gram }=\frac{0.25 \text { gram }}{1000}=0.00025 \mathrm{~kg} \\
& \text { so, } \mathrm{np} \quad=\frac{\mathrm{Q}}{\mathrm{m} . \mathrm{z}} \times \frac{1 \text { hour }}{60 \text { minutes }} \\
& =\frac{15 \mathrm{~kg} / \text { hour }}{0.00025 \mathrm{~kg} / \text { rot } x 4} \times \frac{1 \mathrm{jam}}{60 \text { minutes }} \\
& =250 \mathrm{rpm}
\end{aligned}
$$

\subsection{Determining Power and Torts Required for Milling}

Based on the calculation of the known corn seed milling force, then the estimated plan power needed, to calculate the plan power $(\mathrm{P})$ first calculates the torque generated from the corn seed milling force that occurs $(T)$, namely:
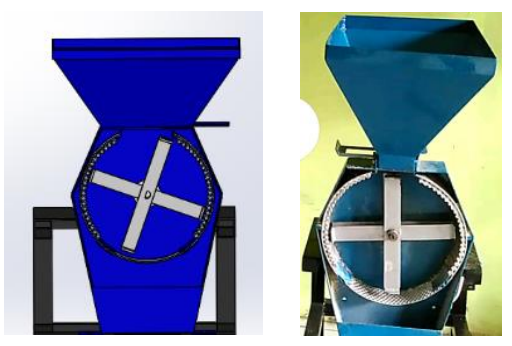

Figure 5. Milling force on a grinding blade

a) The torque acting on the blade

Consists of 2 type I and 2 U-type blades

JEMMME | Journal of Energy, Mechanical, Material, and Manufacturing Engineering 
- Total blade length $=260 \mathrm{~mm}$

$-1 / 2$ Blade length $(r)=130 \mathrm{~mm}$

- Milling force $(F)=87.85 \mathrm{~N}=8.96 \mathrm{~kg}$

$$
\begin{aligned}
\mathrm{T} & =\mathrm{F} \times \mathrm{r} \\
& =8.96 \mathrm{~kg} \times 130 \mathrm{~mm} \\
& =1164.8 \mathrm{~kg} . \mathrm{mm}
\end{aligned}
$$

b) Machine power needed

$$
\begin{aligned}
\mathrm{P} & =\frac{T \cdot n}{9.74 \times 10^{5}} \\
& =\frac{1164.4 \mathrm{~kg} \cdot 250 \mathrm{rpm}}{9.74 \times 10^{5}} \\
& =0.298 \mathrm{~kW} \\
& =0.40 \mathrm{HP}
\end{aligned}
$$

So the electric motor power needed to drive the engine is $0.298 \mathrm{~kW}$ (298 Watts) or $0.40 \mathrm{HP}$ horsepower. So planning to use an electric motor that is already available in the market that is close to the calculation results is an electric motor with a power of 372 Watts $(0.37 \mathrm{~kW})$ or $0.50 \mathrm{HP}$ with a turn of $1400 \mathrm{Rpm}$.

From the results of the calculation of the electric motor power needed to chop the grass, get the results of $0.072 \mathrm{KW}$ or $0.10 \mathrm{HP}$. As for the results of the calculation of the electric motor power needed to grind corn kernels get the results of $0.298 \mathrm{KW}$ or $0.40 \mathrm{HP}$. So the estimation in the selection of electric motors used in the optimization of multifunctional engine design for the manufacture of animal feed using the selection of electric motors with engine power specifications of $0.50 \mathrm{HP}$ with a rotation of $1400 \mathrm{Rpm}$.

\subsection{Dinamo Electric Motor 1 Phase 0.50 HP}

Dynamo electric motor is one of the most important main component parts in optimizing the design of multifunction machines for the manufacture of animal feed, because these components are the driving force of the components of the blade grinder and chopper and other components. The electric motor used is 1 phase $1 / 2 \mathrm{HP}$, here are the specifications:

$$
\begin{array}{ll}
\text { Type } & : \text { JYIA-4 } \\
\text { Power } & : 0,4 \text { HP } \\
\text { Rotation } & : 1400 \text { RPM } \\
\text { Voltage } & : 110 / 220 \mathrm{~V}
\end{array}
$$

Next is the Dinamo Electric Motor 1 phase $0.50 \mathrm{HP}$, seen in picture 6:

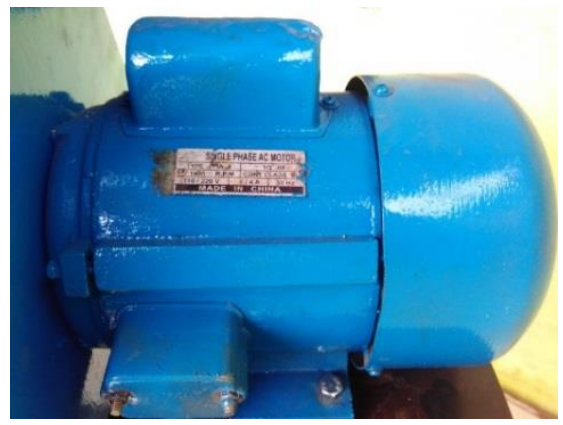

Figure 6. Dynamo ADK Electric Motor Type JYIA-4 1 phase $0.50 \mathrm{HP}$ 


\subsection{Determining The Grass Cutting Force}

In determining the style of cutting grass, first calculate the mass of grass odot / pandanus leaves. To find out the magnitude of the cutting force that occurs in the odot grass is done by empirical testing by placing the blade perpendicular to the balance, then pressed the grass odot / pandanus leaves the blade is cut off, then the balance sheet will show how much load is generated from the test three times.

The following is a test of the odot grass mass shown in figure 7 below:

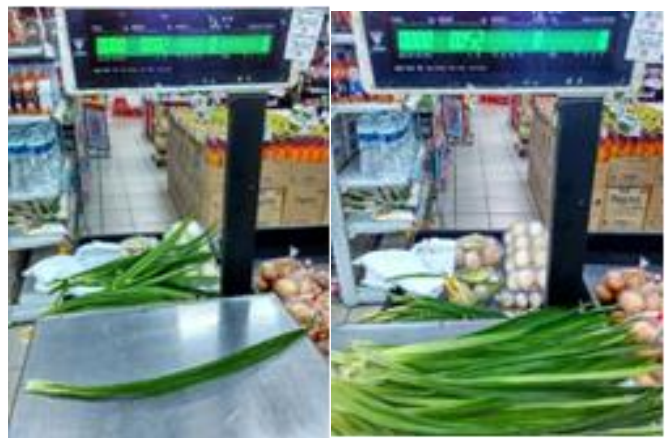

Figure 7. Measurement of grass mass

Table 2. Load testing data on odot grass

\begin{tabular}{cc}
\hline Experiment & Load $(\mathbf{k g})$ \\
\hline 1 & 3.3 \\
2 & 3.1 \\
3 & 3.2 \\
\hline average & 3.2 \\
\hline
\end{tabular}

\subsection{Manufacture of Multifunction Machines Components \\ Main Machine Frame}

The planned frame size is an overall length of $40 \mathrm{~cm}$, width of $40 \mathrm{~cm}$ and height of $65 \mathrm{~cm}$ using $3 \times 3 \mathrm{~mm}$ hollow iron material, as shown in figure 8 .

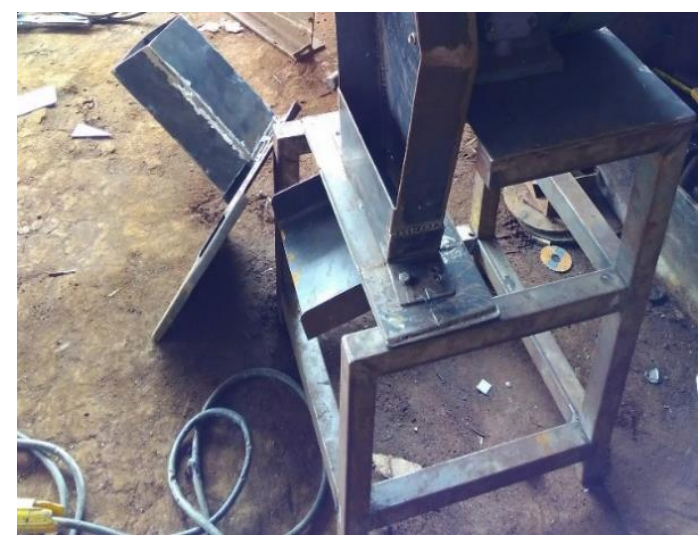

Figure 8. Main machine frame

After the engine frame is made next is the making of the holder for the electric motor holder. The plate used in the manufacture of the main frame of multifunctional animal feed making machine which has a diameter of $60 \mathrm{~mm}$ electric motor as a hole. 


\begin{tabular}{ccc}
\hline \multicolumn{2}{c}{ Table 3. Specifications of the Main Machine Frame } \\
\hline Specification & Dimension & Material \\
\hline length & $330 \mathrm{~mm}$ & \\
width & $70 \mathrm{~mm}$ & ST37 C $(0.17-0.20 \%)$ \\
high & $455 \mathrm{~mm}$ & DIN 1710 \\
plate thickness & $3 \mathrm{~mm}$ & \\
diameter of the seat hole & $60 \mathrm{~mm}$ & \\
\hline
\end{tabular}

\section{Machine Loose Frame}

After making the main frame of the machine the next stage is making the frame off the engine, the material used is the same as the material for the framework of planting machines, namely iron plate size $3 \mathrm{~mm}$ plate thickness.

Table 4. Specifications of the Machine Loose Frame

\begin{tabular}{ccc}
\hline Specification & Dimension & Material \\
\hline length & $10 \mathrm{~mm}$ & \\
width & $10 \mathrm{~mm}$ & \\
high & $5 \mathrm{~mm}$ & ST37 C $(0.17-0.20 \%)$ \\
thick & $3 \mathrm{~mm}$ & DIN 1710 \\
slope angle of the hopper & $45^{0}$ & \\
length $x$ width of hopper & $10 \times 10 \mathrm{~mm}$ & \\
total hopper height & $260 \mathrm{~mm}$ & \\
\hline
\end{tabular}

\section{Milling Hopper}

After making the loose frame, the next step is making a grinding hopper which serves to import corn kernels which will be processed for making animal feed.

Table 5. Specifications of the Milling Hopper

\begin{tabular}{ccc}
\hline Specification & Dimension & Material \\
\hline length & $41 \mathrm{~mm}$ & ST37 C (0.17-0.20\%) \\
width & $30 \mathrm{~mm}$ & DIN 1710 \\
high & $3 \mathrm{~mm}$ &
\end{tabular}

Following is the process of making a grinding hopper shown in Figure 9.

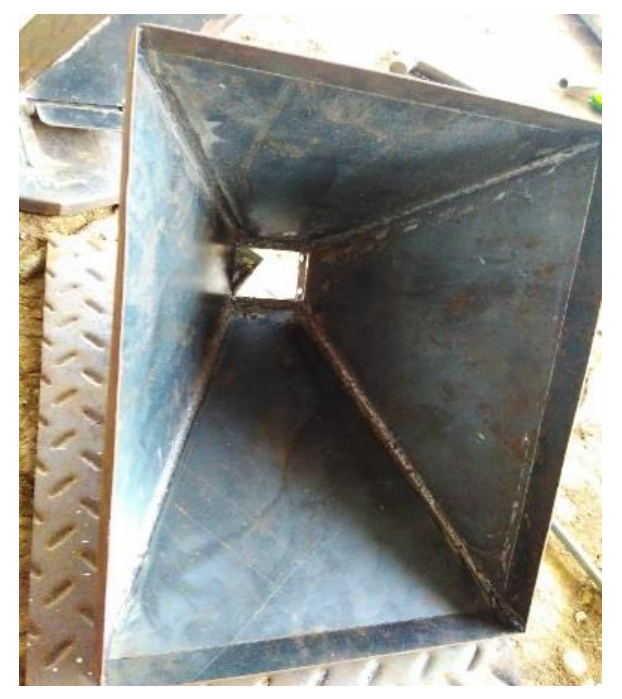

Figure 9. Milling Hopper 


\section{Milling Pounder Gear}

Manufacture of milling pounder gear, serves to grind corn seeds between U-plate blades with pounding gear which will be processed for the manufacture of animal feed.

Table 6. Specifications of the Milling Pounder Gear

\begin{tabular}{cccc}
\hline Specification & Dimension & Material & Quantity \\
\hline length & $250 \mathrm{~mm}$ & & \\
width & $70 \mathrm{~mm}$ & ST37 Steel & 3 blades \\
thick & $5 \mathrm{~mm}$ & & \\
high & $64 \mathrm{~mm}$ & & \\
\hline
\end{tabular}

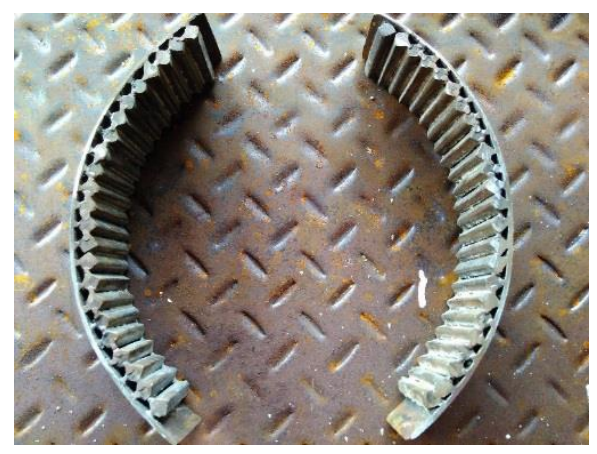

Figure 10. Milling Pounder Gear

\section{Manufacture of Type U Plate Blade}

After the manufacture of milling pounder gear, the next stage is the manufacture of U-type plate blade, this for serves to grind corn seeds between U-type plate blade with pounder gear which will be processed for the manufacture of animal feed.

Table 7. Specifications of Type U Plate Blade

\begin{tabular}{cccc}
\hline Specification & Dimension & Material & Quantity \\
\hline length & $260 \mathrm{~mm}$ & & \\
width & $30 \mathrm{~mm}$ & ST37 Steel & 3 blades \\
thick & $5 \mathrm{~mm}$ & & \\
high & $30 \mathrm{~mm}$ & & \\
\hline
\end{tabular}

Next is the process of making type $\mathrm{U}$ plate blade shown in Figure 11.

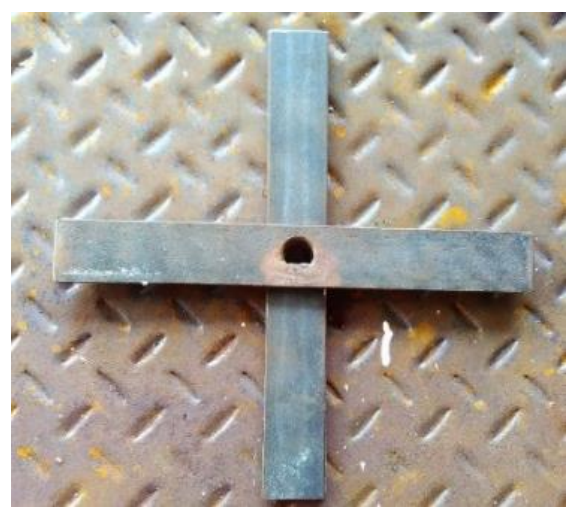

Figure 11. Type U Plate Blade 


\section{Manufacture of Type I Plate and Chopper Blades}

After making the $U$ plate blade, the next step is making a plate I blade,functions the same as a U-plate, namely as a grinder to grind corn seeds between plate I blades with pounding teeth to be processed for animal feed.

The blade is made manually by first cutting to the desired size. Then given a middle hole for the shaft inlet and made 2 blades sharpened using a grinding, then the shaft chopper blade is smoothed using a grinding.

Table 8. Specifications of Type I Plate and Chopper Blade

\begin{tabular}{cccc}
\hline Specification & Dimension & Material & Quantity \\
\hline $\begin{array}{c}\text { length } \\
\text { width }\end{array}$ & $260 \mathrm{~mm}$ & & \\
thick & $30 \mathrm{~mm}$ & ST37 Steel & 3 blades \\
\hline
\end{tabular}

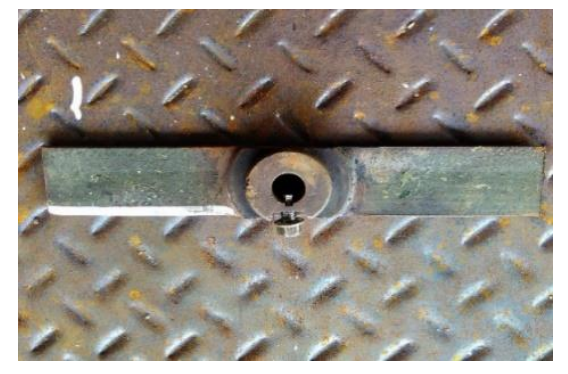

Figure 12. Chopper Blade

\section{Regulating plate for inclusion of the grinding hopper}

After making the grinding hopper all have been processed, the next step is making hopper insertion plate, material ST37 with a length of $100 \mathrm{~mm}$, width of $60 \mathrm{~mm}$, and thickness of $5 \mathrm{~mm}$, used to regulate the entry of corn seeds from the hopper that will enter the milling machine. This control plate is made manually by first cutting to the desired size. Then given a middle hole for the corn seed inlet.

Table 9. Specifications of the regulating plate for the inclusion of the grinding hopper

\begin{tabular}{ccc}
\hline Specification & Dimension & Material \\
\hline length & $100 \mathrm{~mm}$ & \\
width & $60 \mathrm{~mm}$ & ST37 C (0.17-0.20\%) \\
high & $5 \mathrm{~mm}$ & \\
\hline
\end{tabular}

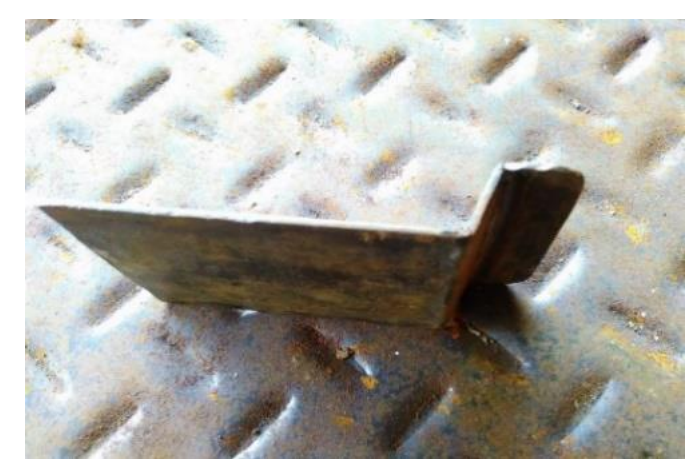

Figure 13. Regulating Plate 


\section{Thick Plate Milling Filter}

The function of this filter component is to filter the results of maize seed grinding from the rough grinding process, (the rotor mechanism used is a 20 mesh sieve which means that every 1 inch square has 20 holes).

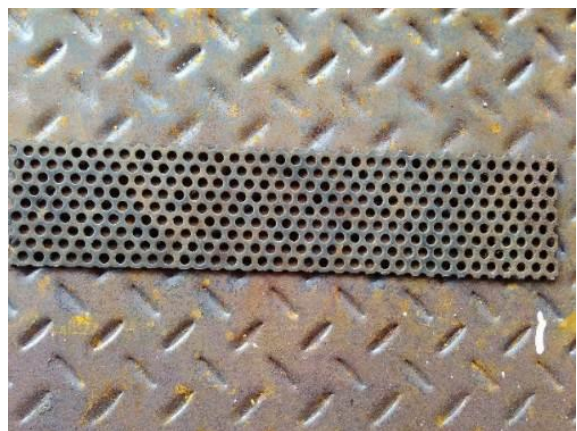

Figure 14. Milling Filter

Table 10. Specifications of the Milling Filter

\begin{tabular}{cc}
\hline Specification & Dimension \\
\hline length & $250 \mathrm{~mm}$ \\
width & $70 \mathrm{~mm}$ \\
diameter & $5 \mathrm{~mm}$ \\
mesh & 20 mesh \\
\hline
\end{tabular}

\section{Trolley Wheel}

Swivel $50 \mathrm{~mm}$ rubber trolley wheels are rubber wheels that can be used on the engine frame to support the engine frame and other components such as motors, main frame and other hopper frames. Its function is to facilitate multifunction machines if you want to be moved from one place to another.

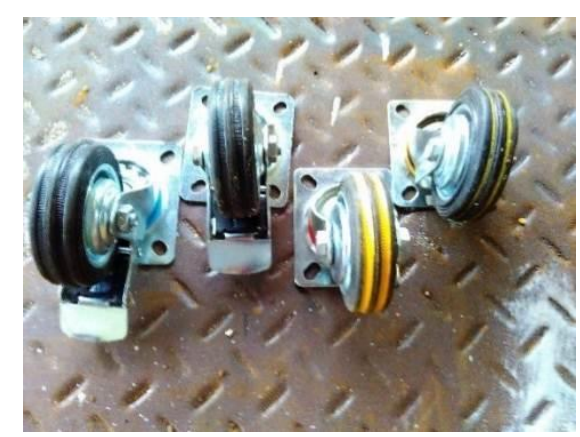

Figure 15. Rubber Trolley Wheel (Swivel $50 \mathrm{~mm}$ )

\subsection{Assembling Components}

After all the components have been made, the next step is to assemble the entire engine frame. To assemble parts into a multifunctional machine frame for making animal feed, welding and other binding components are needed (nuts and bolts), these nuts and bolts are used to bind or unite the electric motor holder with the engine frame along with other components. 


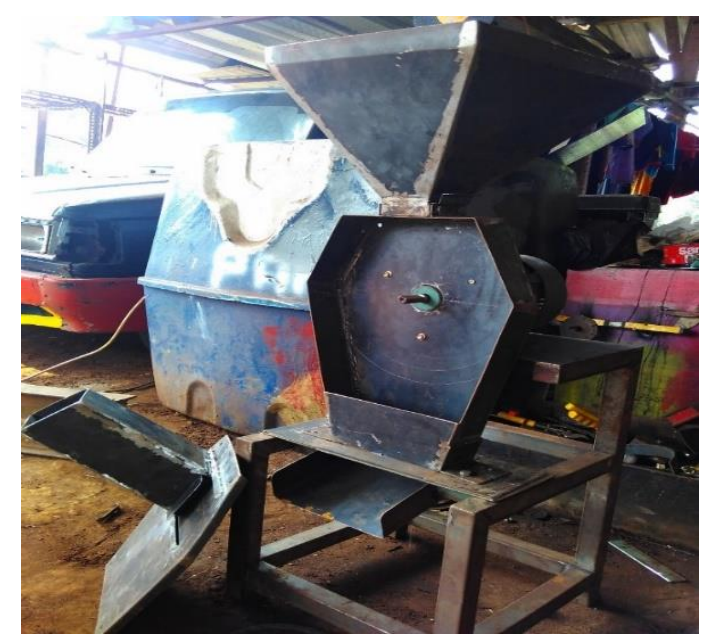

Figure 16. Frame components after assembly

The transmission system for the optimization of multifunctional machine design for the manufacture of animal feed uses an electric motor shaft system. The use of this system was chosen because it was more efficient than using a pulley transmission system and other belt systems or transmission systems due to the application of this tool that no one had made a direct system on electric motors for milling and scaling machines. So this system was chosen as an optimization of the design of multifunctional machines for the manufacture of animal feed.

\subsection{Multifunctional Machine Testing}

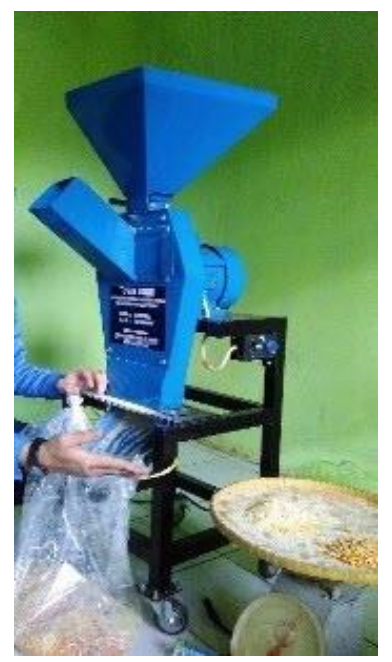

Figure 17. Test the Performance of Multifunctional Machine

\section{Test the performance of milling for grass weaving}

- Time $=50 \mathrm{~s}$

$$
\begin{aligned}
& =50 \mathrm{~s}+10 \% \\
& =50+10 \% \text { dari } 50 \mathrm{~s} \\
& =50+10 \times \frac{50}{100} \\
& =50+5
\end{aligned}
$$




$$
=55 \mathrm{~s}
$$

- 1 hour $=\frac{3600 s}{55 s}=65$ times

- 65 times $\times 970$ gram $=63490$ gram

$$
=\frac{63490}{1000}=63 \mathrm{~kg}
$$

\section{Test the performance of milling for dried corn seeds}

- Time $=60 \mathrm{~s}$

$=60 \mathrm{~s}+10 \%$

$=60+10 \%$ from $55 \mathrm{~s}$

$=60+10 \times \frac{60}{100}$

$=60+6$

$=66 \mathrm{~s}$

- 1 hour $=\frac{3600 s}{66 s}=54,5$ times

- 54,5 times $\times 950 \mathrm{gram}=51818 \mathrm{gram}=51,8 \mathrm{~kg}$

\section{Conclusion}

Based on the results and discussion, conclusions can be drawn as follows: The rotation speed of the AC electric motor is $1400 \mathrm{Rpm}$, the frequency is $50 \mathrm{~Hz}$, and horsepower is $0.5 \mathrm{HP}$. The best results of the knitting or milling test are 50 seconds for different test pieces and milling, with the output of $63 \mathrm{~kg}$ and $51.8 \mathrm{~kg}$ milling output. The time needed to complete the multifunction machine for \pm 20 days or 28800 minutes.

The suggestions in the process of designing a multifunctional machine that needs to be considered is in determining the rotation speed of the blade and the selection of an electric motor that must match the number of blades planned. For maximum results, it is necessary to increase the number of blades used to increase the capacity of the desired results.

\section{REFERENCES}

[1] Afi Sodik, Kun Suharno, Sri Widodo. 2016. Perancangan Mesin Pengupas Kopi Dengan Menggunakan Dua Rol Pengupas. Jurnal WAHANA ILMUWAN Vol 1 No 1 , Hal.55-64

[2] Edo Widya Muda Pradana. 2015. Rancang Bangun Mesin Pencacah Rumput Laut Skala UKM. Jurnal Rekayasa Mesin Vol 2 No 2, Hal.11-16

[3] Riki Effendi, Muhammad Khumaidi. 2018. Perancangan Mesin Perajang Bawang Serbaguna Menggunakan Motor Listrik Dengan Kapasitas $55 \mathrm{Kg} / \mathrm{Jam}$. Jurnal POLIMESIN Vol 16 No 2, Hal.47-50

[4] Sularso. 2008. Dasar Perencanaan dan Pemeliharaan Elemen Mesin. PT Pradnya Paramita, Jakarta

[5] Mott, Robert L. 2009. Elemen-Elemen Mesin Dalam Perancangan Mekanis. Penerbit ANDI, Yogyakarta

[6] Karmiadji, Djoko W. 2011. Optimasi Desain: Material, Komponen, Konstruksi. Engineering Clinics FTUP.

[7] Giesecke, Frederick E; Mitchell, Alva; Spencer, Cecil Henry. Technical Drawing with Engineering Graphics. Prentice Hall, 2016.

[8] Wikipedia.org. 2017. Motor Listrik. https://id.wikipedia.org/wiki/Motor listrik. 
[9] Bose, Bimal K. Power Electronics and Motor Drives: Advances and Trends. Academic Press, 2006.

[10]Degarmo, E. Paul; Black, J T.; Kohser, Ronald A. Materials and Processes in Manufacturing (9th ed.). John Wiley \& Sons, 2003.

[11] Khurmi, R.S \& Gupta, J.K. A Text Book of Machine Design. Eurasia Publishing House (Pvt) Ltd, 2005.

[12] Ugural, Ansel CMechanical Design: An Integrated Approach. New York: McGraw-Hill Companies, 2004.

[13] Kalpakjian, Serope; Steven R. Schmid. Manufacturing Engineering and Technology. Prentice Hall, 2009.

[14] Ulrich, Karl T. Product Design and Development. New York: McGraw-Hill Companies, 2012.

[15] Magrab, Edward B. Integrated Product and Process Design and Development. New York: CRC Press, 2010. 